DOE/ NASA CONTRACTOR

DOE /NASA CR-161382 REPORT

\title{
QUALIFICATION TEST PROCEDURES AND RESULTS FOR HONEYWELL SOLAR COLLECTOR SUBSYSTEM, SINGLE-FAMILY RESIDENCE
}

Prepared from documents furnished by

Honeyweil, Inc.

Energy Resources Center

2600 Ri dgway Parkway, N. E.

Minneapolis, Minnesota 55413

Under Contract NAS8-32093 with

National Aeronautics and Space Administration

George C. Marshall Space Flight Center, Alabama 35812

For the U. S. Department of Energy

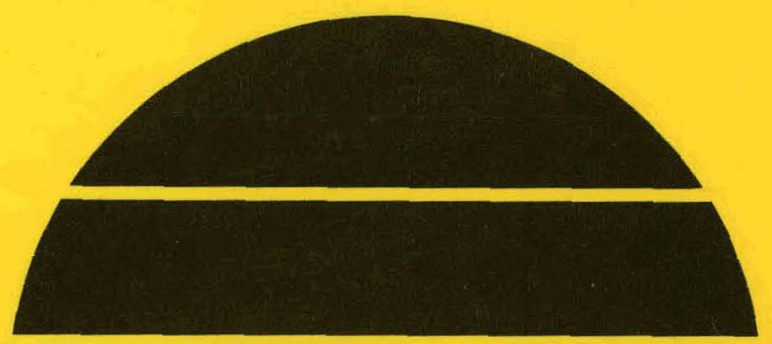

\section{U.S. Department of Energy}




\section{DISCLAIMER}

This report was prepared as an account of work sponsored by an agency of the United States Government. Neither the United States Government nor any agency Thereof, nor any of their employees, makes any warranty, express or implied, or assumes any legal liability or responsibility for the accuracy, completeness, or usefulness of any information, apparatus, product, or process disclosed, or represents that its use would not infringe privately owned rights. Reference herein to any specific commercial product, process, or service by trade name, trademark, manufacturer, or otherwise does not necessarily constitute or imply its endorsement, recommendation, or favoring by the United States Government or any agency thereof. The views and opinions of authors expressed herein do not necessarily state or reflect those of the United States Government or any agency thereof. 


\section{DISCLAIMER}

Portions of this document may be illegible in electronic image products. Images are produced from the best available original document. 
NOIICE

This report was prepared to docunent work sponsored by the United States Governmen:. Nesther the United States nor Ifs agents the Unfted States Department of Energy, the United States Natlonal Aeronautice and Space Adridalseration, nor any federal employees, nox any of thel: contractors, subcontractors or their employeea, wake any wartancy, express or implied, or assume any lega? 14 Libl1Ey or responstbility for the accuracy, completeness, or lisefulness of any information, apparatus, product or procase disclosed, or represent that its use would not infringe privateiy owned rights. 
TECHNICAL REPORT STANDARD TITLE PAGE

\begin{tabular}{|c|c|}
\hline $\begin{array}{l}\text { 1. REPORT NO. } \\
\text { DOE / NASA CR-161382 }\end{array}$ & 3. RECIPIENT'S CATALOG NO. \\
\hline \multirow{2}{*}{$\begin{array}{l}\text { 4. TITLE AND SUBTITLE } \\
\text { Qualification Test Procedures and Results for Honeywell Solar } \\
\text { Collector Subsystem, Single-Family Residence }\end{array}$} & $\begin{array}{l}\text { 5. REPORT DATE } \\
\text { February } 1977\end{array}$ \\
\hline & 6. PERFORMING ORGANIZATION CODE \\
\hline 7. AUTHORIS) & 8. PERFORMING ORGANIZATION REPORT \\
\hline \multirow{3}{*}{$\begin{array}{l}\text { 9. PERFORMING ORGANIZATION NAME AND ADDRESS } \\
\text { Honeywell, Inc. } \\
\text { Energy Resources Center, } 2600 \text { Ridgway Parkway, N. E. } \\
\text { Minneapolis, Minnesota } 55413\end{array}$} & 10. WORK UNIT, NO. \\
\hline & $\begin{array}{l}\text { 11. CONTRACT OR GRANT NO. } \\
\text { NAS8-32093. }\end{array}$ \\
\hline & 13. TYPE OF REPORI \& PERIOD COVERED \\
\hline \multirow{2}{*}{$\begin{array}{l}\text { 12. SPONSORING AGENCY NAME AND ADORESS } \\
\text { National Aeronautics and Space Administration } \\
\text { Washington, DC } 20546\end{array}$} & Contractor Report \\
\hline & 14. SPONSORING AGENCY CODE \\
\hline
\end{tabular}

This work was done under the technical management of Mr. J. Parker, George C. Marshall Space Flight Center, Alabama.

18. ABSTRACT

This document describes the test procedures and results in qualifying the Honeywell solar collector subsystem. Testing began in mid-August, 1976, and was concluded in late February, 1977. Testing was done in the following areas: pressure, service loads, hail, solar degradation, pollutants, thermal degradation and outgassing. Results from these tests are summarized in this report.

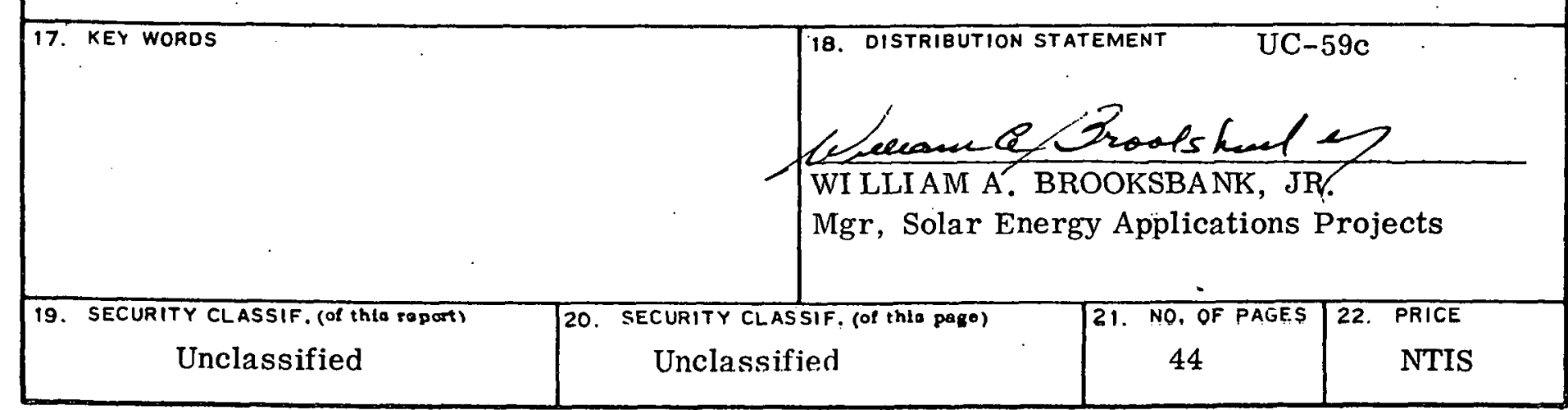


THIS PAGE

\section{WAS INTENTIONALLY LEFT BLANK}


1. Scope

Page

2. Schedule: 1

3. Test Procedures 1

Table 1 Collector Subsystem Qualification Tests 2

Figure 1 Collector Subsystem Qualification Test 3

Schedule

Attachment A Collector Efficiency Detailed Test $\cdot$ A-1 Procedure

Attachment B. Collector Test and Results B-1

This book was prepared as an account of work sDonsored by an agency of the United States Government. Neither the United States Government nor any agency thereof, nor any of their employees. makes ony warranty. express or impligd, or assumes any legal hibbihty or responsibiniy los he accuracy. completeness. or useithess of any intormation; apparalus. product. or process to any specific

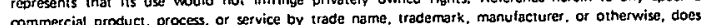

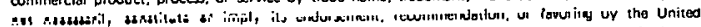
States Government or any agency thereof. The viows and opinions of authors expressed herein do not necessarily state of reflect those of the United States Government or any agency thereof. 
1. $\quad \mathrm{SCOPE}$

This document is submitted per item 500-13 of the contract data. Requirements List. It is the plan, i.e., schedule and procedures, that will be followed in qualifying the collector subsystem. Table 1 summarizes the tests involved.

\section{SCHEDULE}

Figure 1 is the schedule for qualifying the collector subsystem. Testing starts in mid August 1976 and ends in late February 1977, a 6.5 month period.

\section{TEST PROCEDURES}

The following detailed procedures define the tests that will be performed on the collector subsystem or elements thereof. Satisfying the prerequisites listed in Table 1 will qualify the collector subsystem for use in the heating and heating/cooling systems.

Attachment A to this document is the detailed test procedure for collector efficiency per Criterion 1.3.1 of Interim Performance Criteria (IPC) Document 98M10001 (28 February 1975). This will be a development rather than qualification test, but the results will bear on qualification of the collector subsystem.

Notification and witnessing will be per Quality Assurance Plan. 
Test/no.

\section{Pressure}

3.1

\section{Service Loads}

3.2

Hail

3.3
Iten Tested

\section{Collector-Lennox} LSC18-1 Collectar-Lennox LSE18-1

LSC18-1 Collector with glass $-(2) 1 / 8$ " :empered $F_{i} / N$

LE2 $828 \leqslant B$

\section{Solar Degradation}

3.4

2 collectors-Lennox

LSC18-1

\section{Pollutants}

3.5

Thermal Degradation

3. 6

\section{Outgassing}

3.7

Collector - Lennox
Normally sipported
Objective

Aszertain no leakage under hydrostatic pressure of 150 psig

Determine ability to withstand a cistributed load of 50 PSF

Determine ability to withstand impact of 1.25 inch ice sphere at $\mathrm{B2} \mathrm{ft} / \mathrm{sec}$.

Measure efficiency after 1 month, examine. After 6 mos. at average 500 langley/day.

Determine if: $\mathrm{O}_{3}, \mathrm{NaCl}, \mathrm{SO}_{2}$ $\mathrm{NO}_{\mathbf{x}} \mathrm{HCl}$, degrade specimens

Age at max, service temperature
De:ermine if outgassing results fram: 3 solar simulator cycles \& i00 day-nite cycles.
Location

Lenr:ox

ER=

ER̃

ExficiencyER:-. AgingLas Vegas, NV or Phoe$\mathrm{n}: \mathrm{x} . \mathrm{AZ}$

GAP

GAP

\section{Pręrequisite}

Less than 1 psi pressure drop in 15 minutes

No structural degradation or failure which would effect functionability

No discernible fluid leakage of collector panel

No excessive physical deterioration. Efficiency data obtained for design information.

No significant finish degradation. Transmittance degradation less than $10 \%$ Seal strength degradation less than $40 \%$.

No significant finish degradation. Transmittance degradation less than $10 \%$. Seal strength degradation less than $40 \%$.

ERC solar Sirrulator

Transmittance must not degrade more than $10 \%$. 
FICURE 1

COLLECTOR SUBSYSTEM

QUALIFICATION TEST SCHEDULE

$\because \cdots \cdot \cdots, \cdots+\cdots, \cdots, \cdots$

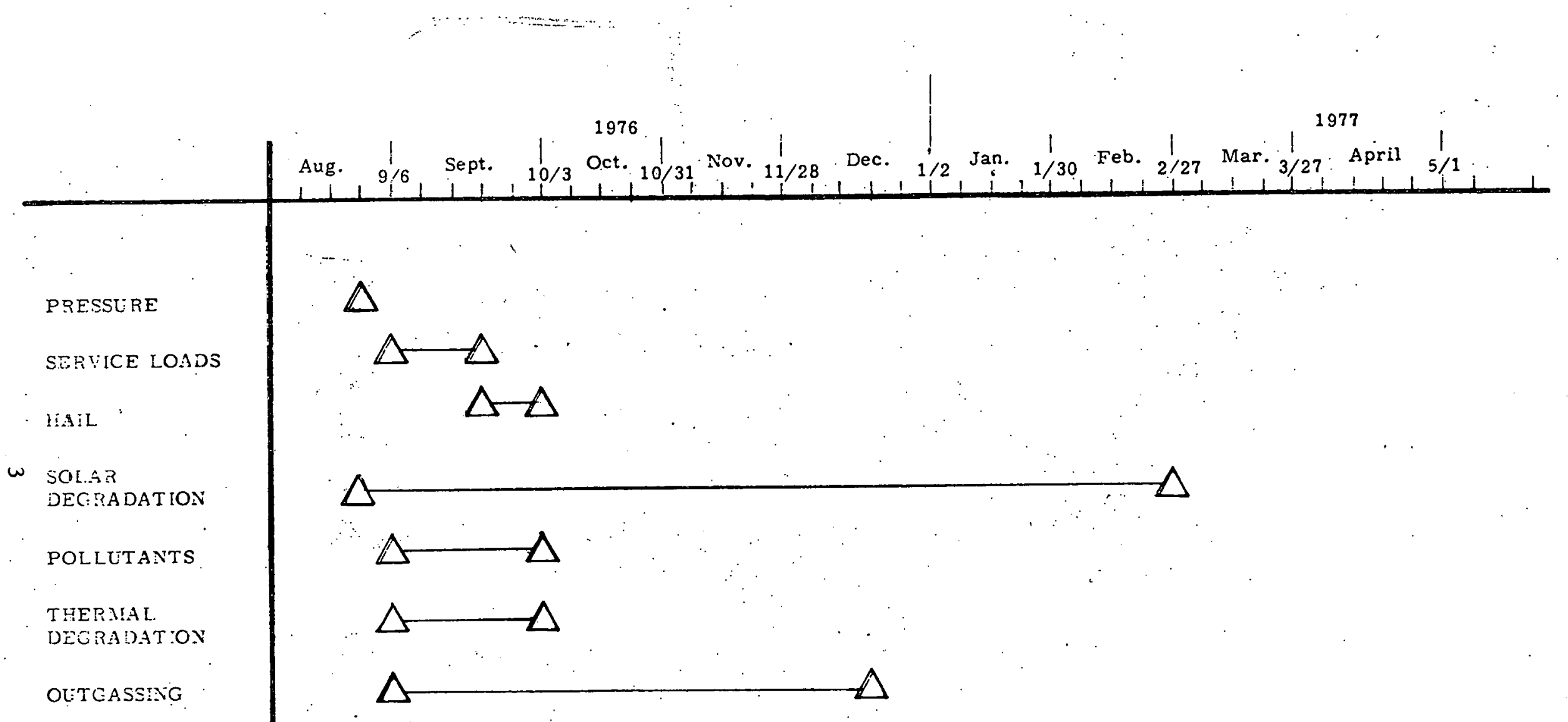


3.1 Pressure Test $-(1 F C 2.3 .1)$

3.1.1 Test Levels

$11 / 2$ times working pressure (Ref. IPC 98M10001 2.3.2)

(1.5) $100=150 \mathrm{psig}$

3.1.2 Test Procedure

o Connect hydraulic piston pump and gauge to inlet of collector

- Pump fluid through collector until fluid exits the outlet.

o. Cap outlet

o. Increase internal pressure to $150 \begin{gathered}+10 \\ -0\end{gathered}$

- Observe gauge for 15 minutes at constant temperature.

- Record beginning and ending pressures on Qualification Test Data Sheet. 
$3.2 \quad$ Service Loads - (IPC 3.1.2)

3.2.1 Test Levels

3.2.1.1 Dead Loads (D)

Include weight of material (negligible) and snow loads.

Ground snow - 40 psf (Ref: HUD 4930.1 601-5)

Roof Coefficient - 0.3 (Ref: HUD 4930.1 601-5)

$D=(40)(0.3)=.12 \mathrm{psf}$

3.2.1.2 Live Loads (L)

$L=(15)\left(\cos 60^{\circ}\right) *=7.5 \mathrm{psf}$

(Ref: HUD 4910.1 601-4.4)

* Based on collector tilt at Northern site which will yield worst case total loads due to snow component

3.2.1.3 Wind Loads (W)

$W=15$ psf (Ref: HUD 4910.1 601-6.2 a,f)

The worst case load combination is as follows: (Ref: IPC $98 \mathrm{M} 100013.2 .1)$

$$
\begin{aligned}
& P=(1.1) D+(1.3) L+(1.7) W \\
& P=13.2+9.75+25.5 \\
& P=48.45 \text { psf }
\end{aligned}
$$




\subsubsection{Test Procedure}

- Mount collector horizontally on a simulated roof mount which supports the collector as installed.

- Distribute sand bags approximately $30 \mathrm{lb}$. each uniformly on surface of collector until a distributed load of $50_{-0}^{+5}$ psf has been attained.

- Examine and record the location and extent of any plastic deformation or failure that occurs.

- Record on Qualification Test Data Sheet.

o. For information only continue to load until plastic deformation occurs. 
3.3 Hail Size and Loading - (IPC 3.7.1)

3.3.1 Test Levels

Mean annual days with hail $=4$

(Ref: 1PC 98M10001 Figure 3.7.1)

Simulated hail size:

$\mathrm{d}=(0.3)(4)=1.20$ inches

(Ref: IPC 98M10001, 3.7.1)

Hail Velocity --1.25 inch hail $=82 \mathrm{ft} / \mathrm{sec}$.

(Ref: NBS Building Science Service 23, Table 1)

Note: The above levels will qualify the material for areas of the United States except the Western Plains and some Rocky Mountain Areas. Using the above references, levels for these areas are:

Western Plains -- 2 inch diameter, $105 \mathrm{ft} / \mathrm{sec}$. Rocky Mountains (Denver area) --2.5 inch, $117 \mathrm{ft} / \mathrm{sec}$. Rocky Mountains (Cheyenne area) -- $3.0 \mathrm{inch,} 130 \mathrm{ft} / \mathrm{sec}$.

\subsubsection{Test Procedure}

The following procedure is in addition to the test method and test. set-up described in National Bureau of Standards, Building Science Services, Number 23, August 1969. 
- Set-up specimen stand timing section, and compressed gas launcher as shown in Figure 2 of referenced document (Separate timing section and launcher by about $10 \mathrm{ft}$.)

- Prepare about 12 simulated hailstones of $1.25 \pm 0.05$ inch diameter.

- Place 1/2 inch plywood in specimen stand and launch several hailstones at different launcher pressures until the pressure corresponding to $82 \pm{ }_{0}^{8} \mathrm{ft} / \mathrm{sec}$. is demonstrated to be repeatable.

- Fill collector with fluid (leave small amount of air for expansion) and cap.

- Remove plywood and install collector in stand.

- Launch a $1.25 \pm 0.05$ inch hailstone at $82 \pm{ }_{0}^{8} \mathrm{ft} / \mathrm{sec}$.

- Examine and record condition of specimen on Qualification Test Data Sheet.

- For Engineering information only; repeat above procedure at the following test levels, or until glass fracture occurs..
1. $2.0 \pm 0.1$ ineh,
$105+10 \mathrm{ft}_{\mathrm{i}} / \mathrm{ser}$.
2. $2.5 \pm 0.1$ inch,
$117 \pm 0 \mathrm{ft} / \mathrm{sec}$.
3. $3.0 \pm 0.1 \mathrm{inch}$,
$130+13 \mathrm{ft} / \mathrm{sec}$. 
3.4 Solar Degradation - (IPC 5.1.1)

3.4.1 Test Levels

3.4.1.1 Part A. The requirements of the Interim Performance Criteria will be met by the outdoor exposure option of Section 03 page 65 of NASA Document $98 \mathrm{M} 10001$. Six months exposure of a collector in the Phoenix or Las Vegas area where it has.been established that mean daily solar radiation exceeds 500 langleys.

3.4.1.2 Part B. The requirements of Part B will be met by measuring the efficiency of a collector before and after a one month exposure at the same site.

\subsubsection{Test Procedure}

- Ship two collectors to a test site near either Phoenix, Arizoria or Las Vegas, Nevada after measuring efficiency, as described in Appendix $\mathrm{A}$ of this document.

- Install both collectors in an exposed position facing due south and tilted at an angle of $25^{\circ}$ to the horizontal.

- Age both collectors in this position with no fluid in the tubing.

- After aging for 30 to 32 days, ship one collector back to ERC. Minneapolis .

- Conduct efficiency test on collector as described in Appendix A of this document.

- Record results on Qualification Test Data Sheet. 
Page 10

- After aging for 130 - 182 days, ship the other collector back to ERC, Minneapolis.

- Examine for degradation of seals and finishes and conduct efficiency teat as described in Appendix A of this document.

- Recurd findings on Qualification Test Data Sheat. 
3.5 Airborne Pollutants - (IPC 5.1.3)

3.5.1 Test Levels

$\begin{array}{lll}500 \text { hours } & \text { Ozone Atmosphere } & 50 \pm 5 \mathrm{pphm} / \mathrm{vol} \\ 500 \text { hours } & \text { Salt Spray } & 5 \mathrm{INaCl} / 95 \mathrm{Jl}_{2} \mathrm{O} \\ 500 \text { hours } & \text { Sulfurous Acid }\left(\mathrm{H}_{2} \mathrm{SO}_{3}\right) & 100 \mathrm{ppm} \\ 500 \text { hours } & \text { Nitric Acid }\left(\mathrm{HNO}_{3}\right) & 100 \mathrm{ppm} \\ 500 \text { hours } & \text { Hydrochloric Acid }(\mathrm{HCl}) & 100 \mathrm{ppm}\end{array}$

3.5.1.1 Test Specimens

Coupon Samples (major dimension approximately six inches to 15 inches of the following collector parts.

$\begin{array}{ll}\text { Collector Pan } & \text { LB28287B } \\ \text { Seal Strip } & 40 \text { A2201 } \\ \text { Glass } & \text { LB28283D } \\ \text { Frame } & \text { 40A2601 }\end{array}$

3.5.1.2 Temperature Cycling

For all specimens:

Ozone exposure will be at $73.4 \pm 3.6^{\circ} \mathrm{F}$

Salt spray will be at $95.0_{-3}^{+2^{\circ}} \mathrm{F}$

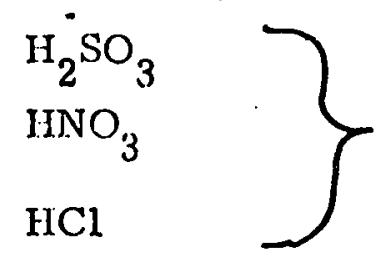

repetitively cycled with one hour at each of the following lemperatures: 


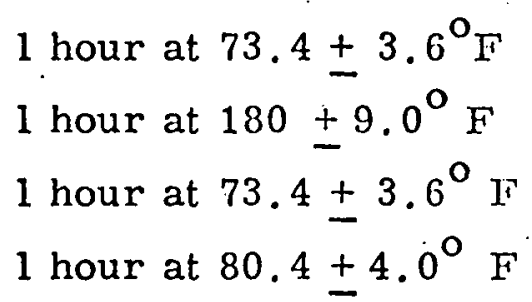

3.5.2 Test Procedure

Ozone: Ref. ASTM D-1149-84 (1970)

$\therefore$ Conduct test per reference

- Record all data on Qualification Test Data Sheet

Salt Spray: Ref. ASTM Standard Method B-117-73

- Conduct test per reference

- Record all data on Qualification Test Data Sheet

$\mathrm{SO}_{2} \cdot \mathrm{NO}_{2}, \mathrm{HCl}$

- Prepare four beakers each of an aqueous solution of $100 \mathrm{ppm}$ $\mathrm{H}_{2} \mathrm{SO}_{3}, \mathrm{HNO}_{3}$ and $\mathrm{HCl}$.

- Immerse one each of each component part in each acid solution.

- Place all 12 beakers in a temperature chamber and cycle between the stated temperature limits.

- After 500 hours of cycling remove and examine for degradation.

3.5,3 Examination Procedure

After all exposures examine exposed and unexposed areas:

- Visually examine all finishes for degradation.

- Test seal strength $P / N 40 A 2201$ with a tensile strength tester in accordance with ASTM D638-72.

- Measure transmittance of glass using a spectrophotometer and method of ASTIM I:424.

- Record all data on Qualification Test Data Sheet. 
Coupon specimens (major dimension approximately six inches to 15 inches) of the following parts will be thermally aged at the following maximum service temperature for a period of 500 hours.

$\begin{array}{llc}\text { Part } & \text { P/N } & \begin{array}{c}\text { Maximum } \\ \text { Service Temp: }\end{array} \\ \text { Glass } & \text { LB28283D } & 280^{\circ} \mathrm{F} \\ \text { Seal Strip } & 40 A 2201 & 280^{\circ} \mathrm{F} \\ \text { Frame } & 40 A 2601 & 280^{\circ} \mathrm{F} \\ \text { Absorber plate } & - \text { LB28282A } & 480^{\circ} \mathrm{F}\end{array}$

Test Procedure

- Place coupon specimens in controlled temperature chambers.

- Age at temperature listed above for 500 hours minimum.

o Inspect for mechanical and finish degradation.

- Conduct tensile strength test per ASTM D638-72 on both aged and unaged specimens of the Seal Strip P/N 40A2201.

- Measure transmittance of 'glass, both aged and unaged specimens ASTM E424.

- Record all data on Quallfication Test Data Sheet. 
3.7 Transmission Losses Due to Outgassing - (IPC 5.2.6)

\subsubsection{Test Levels}

Cycling to maximum service temperature will be accomplished by two means:

1) Three cycles using the Solar Simulator

2) 100 cycles under actual outdoor exposure in thoenix, Arizona or Las. Vegas, Nevada where the mean daily solar radiation exceeds 500 Langleys.

\subsubsection{Test. Procedure}

\subsubsection{Part I}

- Measure transmittance of collector glass by making 18 pyranometer readings in front of and to the rear of the glass on 2 onc foot grid while the glass is expusen] to matural sunlight.

- Install a collector without fluid on stand in the solar simulator facility such that it is normal to the radiation and at least eight feet from the light source.

- Instrument the collector plate with a thermocouple mounted on the back surface of the plate.

- Increase simulated solar flux gradually to a value of $250 \pm$ $25 \mathrm{Btu} / \mathrm{hr}-\mathrm{ft}^{2}$. Vary the rate of increase to achieve maximum plate temperature in two hours.

- Maintain flux for two hours. 
- Gradually reduce flux to zero to achieve room temperature of the plate in 2 hours.

- Repeat this cycle 3 times.

- At the end of three cycles inspect for the presence of condensation on glass. Measure transmittance of the glass using the method above.

- Record on Qualification Test Data Sheet.

\subsubsection{Part II}

- Measure transmittance of a collector glass panel using the method above.

- Ship the collector to a test site near either Phoenix, Arizona or Las Vegas, Nevada.

- Install an exposed position facing due south and tilted at an angle of $25^{\circ}$ to the horizontal. 
- Age in this position without fluid for 100 to 102 days.

- Return to ERC, Minneapolis.

- Inspect and conduct transmittance tests using the method above.

- Record on Qualification Test Data Sheet. 
ATTACHMENT A

Collector Efficiency Detailed Test Procedure

(IPC 1.3:1)

\section{Test Levels}

o All efficiency measurements will be made at a simulated solar flux of $220 \pm 20 \mathrm{Btu} / \mathrm{hr}-\mathrm{ft}^{2}$

- Transfer fluid will be 50/50, $\mathrm{H}_{2} \mathrm{O} /$ Ethylene Glycol. Flow rate of fluid will be $0.35 \pm 0.10 \mathrm{gpm}$.

- Collector inlet temperature levels will be in accord with the following table.

$90^{\circ} \pm 2{ }^{\circ} \mathrm{F}$ above ambient temperature

$125^{\circ} \pm 2^{\circ} \mathrm{F}$ above ambient temperature

$160^{\circ} \pm 2^{\circ} \mathrm{F}$ above ambient temperature

$200^{\circ} \pm 2^{\circ} \mathrm{F}$ above ambient temperature

\section{Test Facilities}

Solar Simulator -- The solar simulator generates a range of flux levels that closely approximates the distribution of the solar spectrum. The simulator consists of 143 projection lamps evenly spared in a square array containing 13 rows and 9 columns. The output from each lamp is collimated by a 6 inch diameter plastic Fresnel lens set in an array 11 inches in front of the lamp array. Using the Fresnel lenses results in a flux output that is es sentially direct radiation, closely simulating actual solar radiation. 
The solar simulator is powered by a 3-phase, 208-volt wye configuration circuit capable of providing 43,000 volt-amperes of power. Each phase of the circuit is monitored by an SCR power controller which restricts the power output from zero to full scale, dependent on an operator-supplied control signal. The full scale output from the solar simulator is $250 \mathrm{Btu} / \mathrm{hr}-\mathrm{ft}$ at a distance of 15 feet from the lens array. This solar simulator is similar in design to that at the NASA-Lewis Research Center, Cleveland; Ohio.

Flow Loop -- The glycol/water mixture is pumped from the reservoir to a 15 foot constant heat tank. An overflow line to return fluid to the reservoir maintains a constant pressure head. This pressure head drives fluid to a conventional hot water heater and then through a constant temperature bath. From the bath the fluid goes through the flowmeter to the collector. The outlet from the collector returns fluid to the reservoir and completes the cycle. $A$ valve placed between the constant temperature bath and the flowmeter regulates the flow.

Mixing cups are inserted at the inletand outlet of the collector. A 6 -junction thermopile and a thermocouple are placed in each mixing cup. From these, the fluid temperature difference across the panel and fluid inlet and outlet temperatures is faund. Another thermocouple placed behind the collector stand measures the ambient temperature. These temperatures are recorded on a digital recorder. Iron-constantan thermocouple wire is used. 
The flow rate is determined using a calibrated flowmeter. As the system approaches steady state, the flow rate is maintained at a constant value. This flow rate is also periodically checked by measuring the time for the return fluid to fill a 1 litre graduated cylinder:

See sketch below:

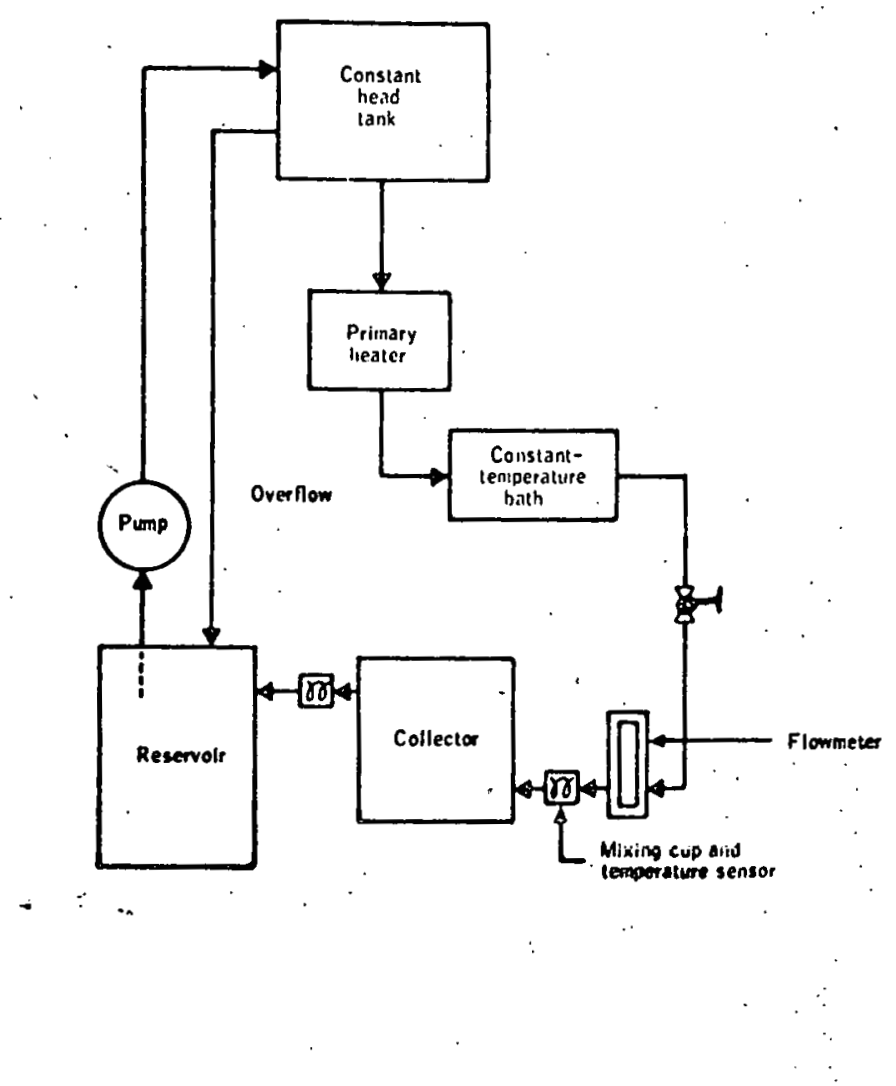

A. Solar radiation measurement:

1. Pyranometer -- Eppley 8-48

2. Digital recorder -- Doric, Digitrend 210

Accuracy (calibrated by Eppley Laboratories) 
B. Temperature measurement:

1. Thermopiles --6-junction - copper constantan

2. Thermocouples -- iron-constantan

$$
\text { accuracy } \pm 0.90^{\circ} \mathrm{F}
$$

C. Flow measurement:

1. Flowmeter - Brooks

accuracy $\pm 1.0 \%$

1. Reference NBSIR 74-635 Method of Testing for Rating Solar Collectors Based on Thermal Performance, Dec. 1974, Paragraph 6. 1.

3. Test Procedure

- Mount collector normal to the radiation and at least 8 feet from solar simulator.

- Install thermocouple on and behind absorber plate.

- Connect to flow loop and bleed all air from system.

- Set solar simulator voltage to a level corresponding to $220 \mathrm{Btu} /$. $\mathrm{hr}-\mathrm{Cl}^{2}$ using the simulator calibration curve. Record voltage.

- Measure flux by installing the Eppley pyranometer at each intersection of a six inch grid over the entire surface of the $3 \times 6 \mathrm{ft}$. collector. Average all readings and record on Qualification Data Sheet.

- Note voltage during the above procedure and adjust if necessary to maintain initial voltage set point. 
- Set flow control valve to $0.35 \mathrm{gal} / \mathrm{min}$. $\left(11.5-13.0 \mathrm{lb} / \mathrm{hr}-\mathrm{ft}^{2}\right)$.

- Adjust colleotor inlet temperature to the first of the four temperature levels.

- Continue to monitor simulator voltage throughout test sequence and adjust if necessary to maintain initial voltage set point.

- When steady state conditions are reached (no measurable change in $\mathrm{T}_{\mathrm{f} ; \mathrm{i}}$ or $\mathrm{T}_{\mathrm{f}, \mathrm{e}}$ ), record the following data for a 15 minute period at 1 minute intervals:

1. Time

2. Ambient temperature $\left(\mathrm{T}_{\mathrm{a}}\right)$

3. Flow rate

4. Collector inlet temperature $\left(\mathrm{T}_{\mathrm{f}, \mathrm{i}}\right)$

5. Collector outlet temperature $\left(\mathrm{T}_{\mathrm{f}, \mathrm{e}}\right)$

6. Plate temperature $\left(\mathrm{T}_{\mathrm{p}}\right)$

- Repeat the above measurements for each of the collector inlet temperature conditions.

- Repeat flux measurement using Eppley pyranometer at the beginning and end of each test day.

- Record data on Qualification Test Data Sheet.

- Reduce data by the method of paragraph 8.4 NBSIR 74-635 Method of Testing for Rating Solar Collectors Based on Thermal Performanre, Deremher 1974. 


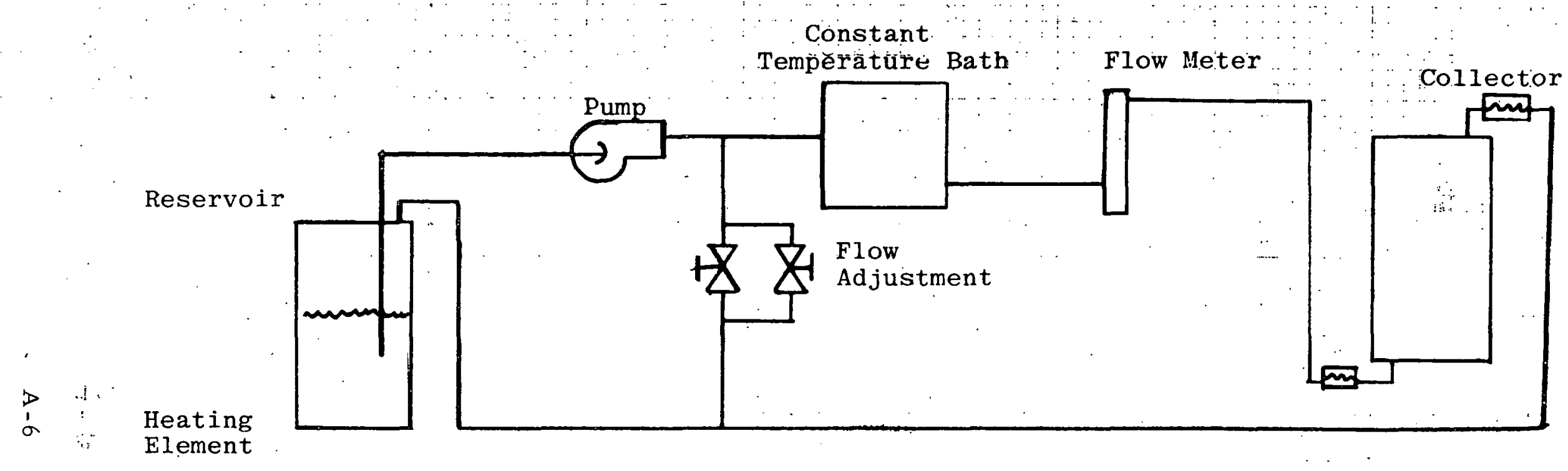

Collector Test Flow Loop 
QUALIFICATION TEST DATA SHEET

$\begin{array}{lll}\text { Subsystem } & \text { Sheet } & \text { Date } \\ \text { Item Tested } & \text { Test Engineer } \\ \text { Part No. } & \text { Witnesses } \\ \text { Serial No. } & \text { Instrumentation } \\ \text { Procedure } & \end{array}$




\section{INDEX}

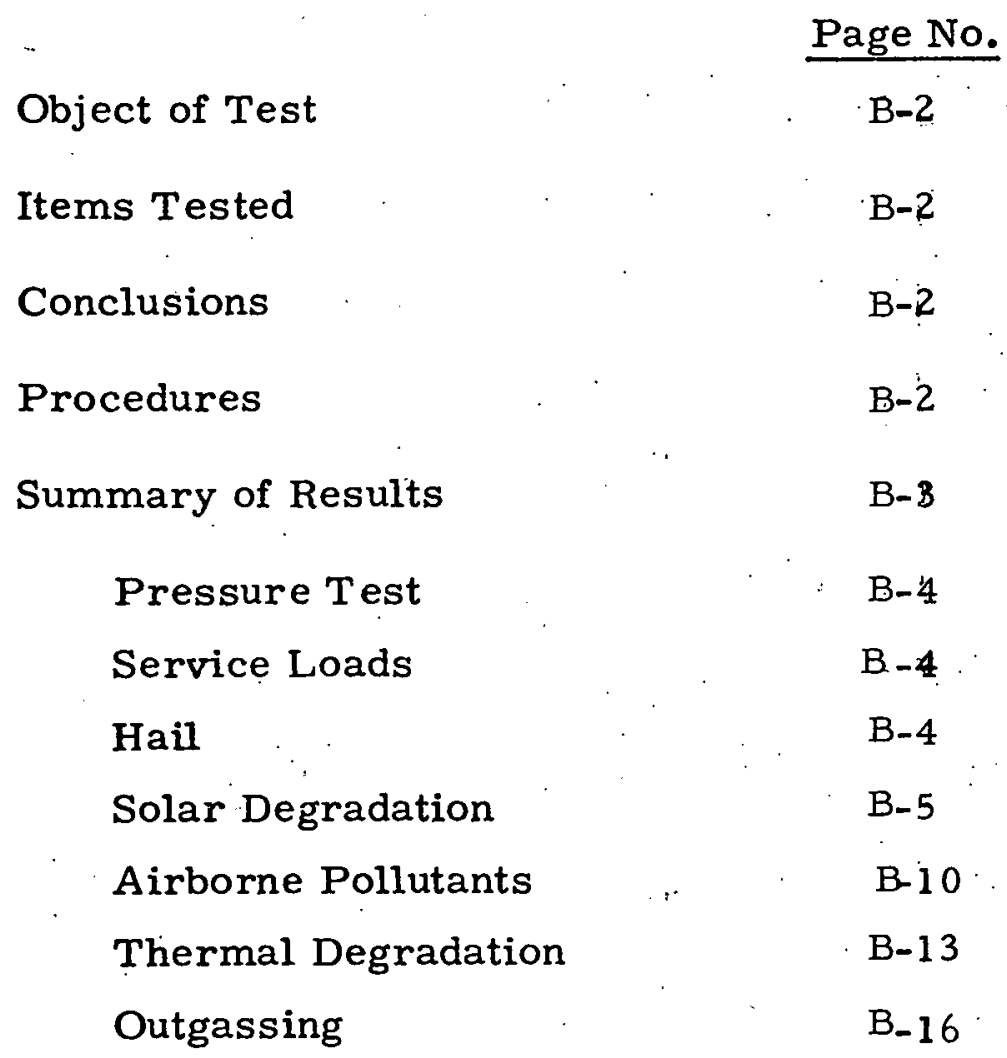


Object of Test

The purpose of this test program is to qualify a solar flat plate collector for use on NASA Contract NAS8-32093. This report satisfies the Data Requirement Item 500-14.

Items Tested

- Four Lennox Model LSC18=1 Sular Collectors serialized as follows:

$$
\begin{aligned}
& 5876-F-14833 \\
& 5876-\dot{F}-14811 \\
& 5876-F-14836 \\
& 5876-F-14835
\end{aligned}
$$

- One Lennox solar absorber plate part number I.R-28282A

- Coupon specimens of Lennox solar collector parts as follows:

$\begin{array}{lll}\text { Collector Pan } & \mathrm{P} / \mathrm{N} & \text { LB28287 B } \\ \text { Seal Strip } & \mathrm{P} / \mathrm{N} & \text { 40A2201 } \\ \text { Glass } & \mathrm{P} / \mathrm{N} & \text { LB28283D } \\ \text { Frame } & \mathrm{P} / \mathrm{N} & 40 \mathrm{~A} 2601 \\ \text { Absorber Flate } & \mathrm{P} / \mathrm{N} & \mathrm{LB} 28282 \mathrm{~A}\end{array}$

Conclusions

The test results reported here in document that the Lennox LSC18-1 collector meets the requirement of contract NAS8-32093.

\section{Procedures}

The following tests were conducted in accordance with test plan Doc F3437-T-101. 
Test/no.

Pressure

3.1

Service Loads

3.2

Hail

3.3

Solar Degradation

3.4

Pollutants

3.5

Thermal Degradation

3.6

Outgassing

3.7
Item Tested

Collector-Lennox

LSC18-1

Normally supported

Collector-Lennox

LSC 18-1

LSC18-1 Collector

with glass - (2) $1 / 8^{\prime \prime}$

tempered $\mathrm{P} / \mathrm{N}$

LB2 $8284 \mathrm{~B}$

2 collectors-Lennox

LSC18-1

Coupon specimens

Coupon specimens

Collector-Lennox
Objective

Ascertain no leakage under hydrostatic pressure of $150 \mathrm{psig}$

Determine ability to withstand a distributed load of 50 PSF

Determine ability to withstand impact of 1.25 inch ice sphere at $82 \mathrm{ft} / \mathrm{sec}$.

Measure efficiency after 1 month, examine. After 6 months at average 500 langley/day.

Determine if: $\mathrm{O}_{3}, \mathrm{NaCl}$, $\mathrm{SO}_{2}, \mathrm{NO}_{\mathrm{X}}, \mathrm{HCl}$, degrade specimens

Age at max, service temperature

Determine if outgassing results from: 3 solar simulator cycles \& 100 day-nite cycles.

Summary of Results

The following summary of results is a condensation of relevant detailed data obtaincd during the test. This data is on file at Honeywell. All data sheets are signed by the test engineer and a representative of DCAS (Defense Contractor Auditing Service). 


\title{
3.1 Pressure Test
}

The objective of this test was to ascertain the ability of the collector absorber plate to withstand a hydrostatic pressure of $150 \mathrm{psig}$. The test was conducted on an absorber plate P/N LB28282A.

Test Level: 158 psig

Prerequisite: Less than 1 psi pressure drop in 15 minutes

Examination: No discernable pressure drop after 30 'minutes.

\subsection{Service Loads}

The objective of this test was to determine the ability of the solar collector to withstand a uniform distributed load of $50 \mathrm{psf}$. The test was conducted on a normally mounted collector S/N $5876-\mathrm{F}-$ 14833.

\author{
Test Level: 78.5 psf \\ Firereluisilu: No structural degradation or fallure whlch \\ would effect funetionability
}

Examination: No permanent deformation was noted following this exposure.

\subsection{Hail}

The objective of this test was to determine the ability of the collector to withstand the loads imposed by hail of 1.25 inch diameter and a velocity of $82 \mathrm{ft} / \mathrm{sec}$. The test was conducted on collector $S / \mathrm{N} 5876$ F-14833. 
Test Level:

(1) 1.25 inch diameter $86.96 \mathrm{ft} / \mathrm{sec}$.

(2) 2.00 inch diameter $107.53 \mathrm{ft} / \mathrm{sec}$.

(3) $2.50 \mathrm{inch}$ diameter $116.27 \mathrm{ft} / \mathrm{sec}$.

(4) $3.00 \mathrm{inch}$ diameter $126.58 \mathrm{ft} / \mathrm{sec}$.

(5) $3.00 \mathrm{inch}$ diameter $131.58 \mathrm{ft} / \mathrm{sec}$.

Prerequisite: No discernable fluid leakage of the collector panel

Examination: No damage due to hail impact on tests 1, 2 and 4. On test number 3 the outer pane of glass shattered. Test number 5 was conducted with a single pane of glass which shattered producing a dent in the absorber panel. A pressure test at 130 psig indicated no leakage.

\subsection{Solar Degradation}

The purpose of this test is to determine the level of efficiency degradation due to exposure to natural sunlight.

Test Level:

A. Six months exposure in Phoenix, Arizona

B. One month exposure in Phoenix, Arizona

Prerequisite: No excessive physical degradation

Examination: Pre exposure efficiency curves are presented in Figures 1 and 2. Post exposure curves are presented in Figures 3 and 4 . The efficiency equations are as follows:

$\begin{array}{lll}\text { Pre exposure } & \frac{\text { One Month }}{0.81-0.70(\Delta T / Q)} \frac{\text { Six Months }}{0.83-0.67}(\Delta \mathrm{T} / \mathrm{Q}) \\ \text { Post exposure } & 0.73-0.58(\Delta \mathrm{T} / \mathrm{Q}) & 0.75-0.62(\Delta \mathrm{T} / \mathrm{Q})\end{array}$




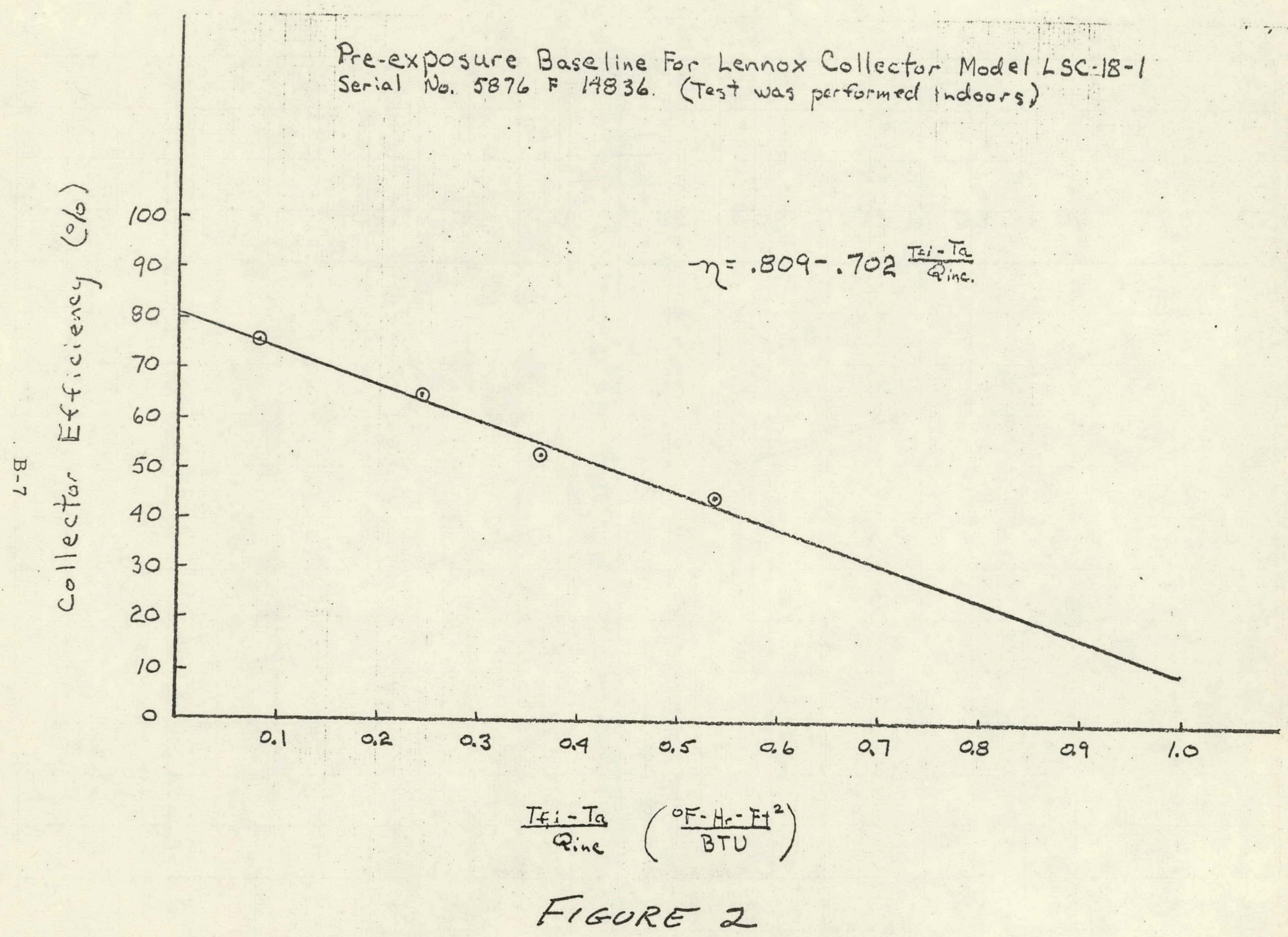




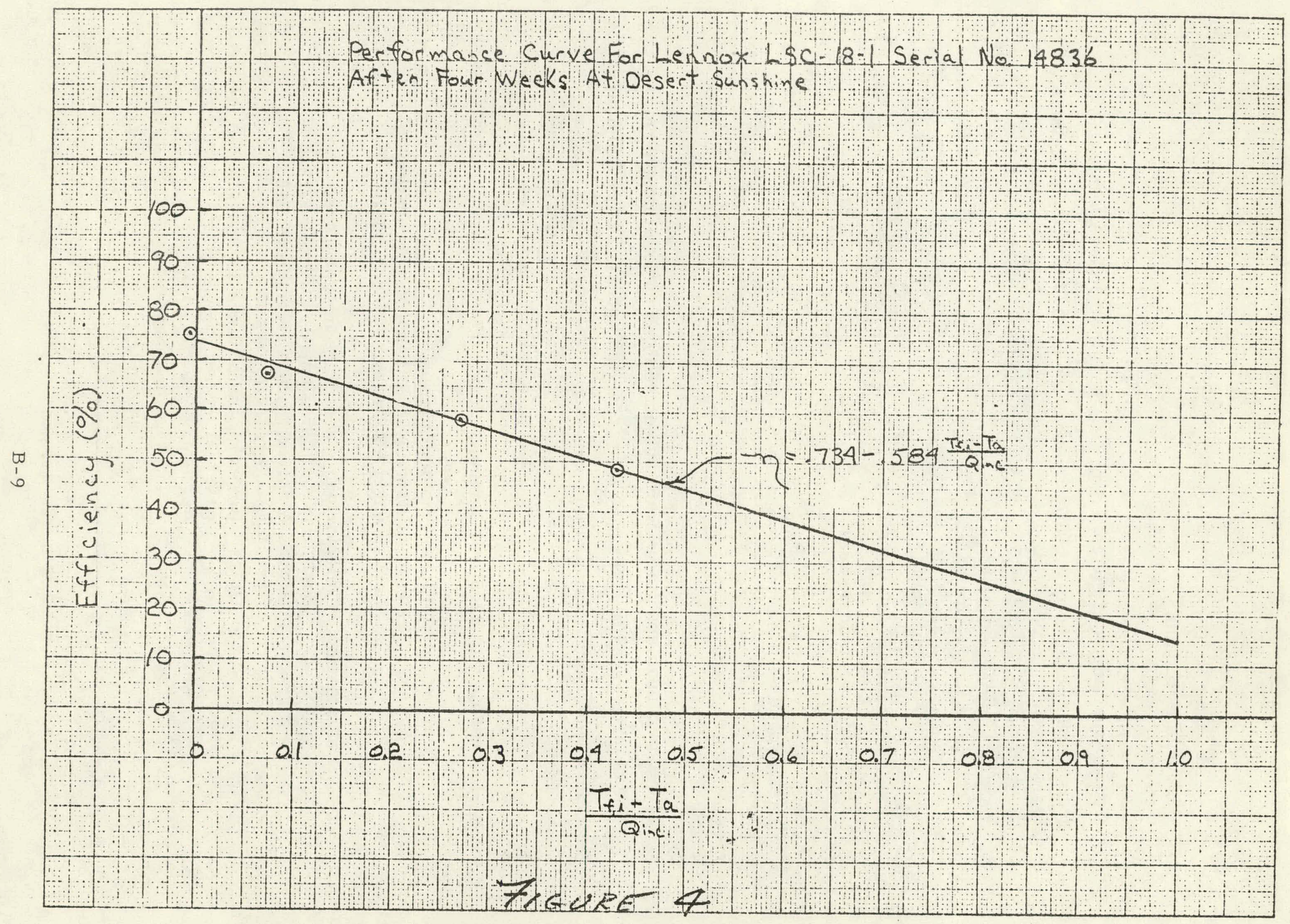


Coupon specimens of the collector pan, seal strip, glass and frame were each subjected to a 500 hour exposure of the following pollutants:
(1) Ozone
(2) Salt spray
(3) Sulfurous acid
(4) Nitric acid
(5) Hydrochloric acid

Each exposure is treated separately below:

\section{A. Ozone}

The four coupon specimens were subjected to an ozone atmosphere. The objective was to determine if degradation occurred after 500 hours at an ozone concentration of $50 \mathrm{pphm}$.

Test Level: $42.5-58.0 \mathrm{pphm}$

Prerequisite: Finish - no degradation

Transmittance - less than $10 \%$ degradation

Seal strength - less than $40 \%$ degradation

Examination: Collector pan - no change in appearance Seal strip - original tensile strength 47.916 final tensile strength 46.516 degradation $3 \%$

Glass - pretest transmittance $93.9 \%$ post test transmittance $93.4 \%$ degradation $0.5 \%$

Frame - no change in appearance 


\section{B. Salt Spray}

The same four coupon specimens were subjected to a salt spray test in accordance with ASTM Method B-117-73.

Test Level: 500 hours at $95^{\circ} \mathrm{F}$

Prerequisite: Finish - no degradation

Transmittance - less than $10 \%$ degradation

Seal strength less than $40 \%$ degradation

Examination: Collector pan - no degràdation

Seal strip - original strength $47.9 \mathrm{lb}$. final strength $48.8 \mathrm{lb}$ degradation - $4 \%$ *

Glass - pretest transmittance $94.3 \%$ post test transmittance $94.1 \%$ degradation $0.2 \%$

Frame - no degradation

C. Sulfurous Acid

This exposure of the coupon specimens is intended to simulate airborne sulfur based pollutants.

Test Level: 500 hours 100 ppm acid

Prerequisite: Finish - no degradation

Transmittance - less than $10 \%$ degradation

Seal strength - less than $40 \%$ degradation

Examination: Collector pan - no significant degradation

Seal strip - original strength $47.91 \mathrm{lb}$ final strength $52.91 \mathrm{lb}$ degradation - $10 \%$

Glass - pretest transmittance $94.9 \%$ post test transmittance $93.8 \%$ degradation $1.1 \%$

Frame - no significant degradation

* perceived increase in strength is probably within the tolerance of the test method. 
D. Nitric Acid

This exposure of the coupon specimens is intended to simulate the effect of Nitrous oxide products in the air.

Test Level: 500 hours at $100 \mathrm{ppm}$ acid

Prerequisite: Finish - no degradation

Transmittance - less than $10 \%$ degradation

Sedl strength - less than $40 \%$ degradation

Examination: Collector pan - no signicant degradation

Seal strength - original $47.9 \mathrm{lb}$

final $49.9 \mathrm{lb}$

degradation $-0.4 \%$

Glass - pretest transmittance $96.0 \%$ post test transmittance $94.1 \%$ degradation $1.9 \%$

Frame - no significant degradation

E. Hydrochloric Acid

Thls exposure of the coupon samples is to simulate airborne hydrochloric acid.

Test Level: 500 hours $100 \mathrm{ppm}$ acid

Prerequisite: Finish - no degradation

Transmittance - less than $10 \%$ degradation

Seal strength - less than $40 \%$ degradation

Examination: Collector pan - no significant degradation

Seal strip - original strength 47.9

final strength 47.8

degradation $<0.1 \%$

Glass - pretest transmittance $93.9 \%$ post test transmittance $93.8 \%$ degradation $0.1 \%$

Frame - no significant degradation 


\subsection{Thermal Degradation}

Coupon specimens of the glass, seal strip and frame were subjected to an exposure of $280^{\circ} \mathrm{F}$ for 500 hours. A coupon specimen of the absorber plate was subjected to an exposure of $480^{\circ} \mathrm{F}$ for 500 hours. These levels were derived from the HUD Interim Performance Criteria. Figure A-3 p. 55, Temperatures at Various Locations in a Collector with a Selective Absorber and Two Glass Cover Plates.

Test Levels: 500 hours

Prerequisite: Finish - no significant degradation Transmittance - less than $10 \%$ degradation Seal strength - less than $40 \%$ degradation

Examination: Absorber Plate - original absorptance 90.0 original emittance 6.7 final absorptance 86.6 final emittance $\quad .6 .0$

Frame - no degradation

Glass - pretest transmittance 94.3 post test transmittance 94.4 degradation $-0.1 \%$

Seal strip - after exposure at $280^{\circ} \mathrm{F}$ the seal strip was so brittle that it was not possible to conduct a strength test on it.

Seal Strip Failure Analysis

An investigation of actual temperatures encountered by the seal strip was conducted at the test site in Phoenix, Arizona. A report of this investigation in the form of a letter from Desert Sunshine Exposure Tests is included here as Figure 5. This data allowed the conclusion that $150^{\circ} \mathrm{F}$ would be a more realistic test level for the seal strip. 


\section{BOX 185 - BLACK CANYON STAGE \\ PHOENIX, ARIZONA 85020.}

(602) 465-7525

February 2, 1977

Mr. Al Baldwin

TAWA

NÜKÉLL, INC.

THE SUN KACHINA

724 Harding Street. N.E.

Minneapolis, Minnesota 55413

Dear Mr. Baldwin:

Listed below are the temperature measurements, and corresponding information, taken on the Honeywell collector coded S/N F14835, covered by Purchase order \#416592-XA, our order No. 17225.

$\begin{array}{lllll}\text { Date } & \text { Time } & \text { Ambient } & \text { Point } & \text { Temp. Insolation } \\ 1 / 28 / 77 & \text { 1:00 p.m. } & 17.0^{\circ} \mathrm{C} & 22 & 54.5^{\circ} \mathrm{C} 1.441 \mathrm{ys} / \mathrm{min} \\ \text { Maximum Plate Temperature } & =195.8^{\circ} \mathrm{C} \text { at } 12: 51 \mathrm{pm}\end{array}$

\begin{tabular}{|c|c|c|c|c|c|c|}
\hline $1 / 28 / 77$ & $1: 00$ & p.m. & $17.0^{\circ} \mathrm{C}$ & 23 & $52.0^{\circ} \mathrm{C}$ & $1.44 \mathrm{lys} / \mathrm{min}$ \\
\hline $1 / 29 / 77$ & $11: 45$ & a.m. & $17.0^{\circ} \mathrm{C}$ & 33 & $40.5^{\circ} \mathrm{C}$ & $0.801 . y s / \mathrm{min}-\mathrm{Cloudy}$ \\
\hline $1 / 29 / 77$ & $11: 45$ & a.m. & $17.0^{\circ} \mathrm{C}$ & 23 & $37.5^{n} \mathrm{C}$ & $0.801 y \mathrm{~s} / \mathrm{min}-\mathrm{Cloudy}$ \\
\hline $1 / 30 / 77$ & $1: 00$ & p.m. & $18.0^{\circ} \mathrm{C}$ & 22 & $51.5^{\circ} \mathrm{C}$ & $1.491 \mathrm{ys} / \mathrm{min}$ \\
\hline $1 / 30 / 77$ & $1: 00$ & p.m. & $18.0^{\circ} \mathrm{C}$ & 23 & $48.0^{\circ} \mathrm{C}$ & $1.491 \mathrm{ys} / \mathrm{min}$ \\
\hline $1 / 31 / 77$ & $12: 30$ & $p \cdot m$. & $18.5^{\circ} \mathrm{C}$ & 22 & & \\
\hline$\pm \operatorname{TS} N 77$ & $12: 30$ & $\underset{\text { Maximum }}{\text { p.m. }}$ & $\begin{array}{l}18.5^{\circ} \mathrm{C} \\
\text { Plate } \mathrm{T}\end{array}$ & $\begin{array}{l}23 \\
\text { erature }\end{array}$ & $\begin{aligned} & 52.0^{\circ} \mathrm{C} \\
&= 202.2^{\circ} \mathrm{C} \\
& 395.6\end{aligned}$ & $\begin{array}{l}1.52 .1 \mathrm{ys} / \mathrm{min} \\
\mathrm{c} \text { at } 12: 30 \mathrm{pm}\end{array}$ \\
\hline
\end{tabular}

Foint \#22 $=$ Between Rubber and Glass - Inner Glass

Point H2.3 - Between Rubber and Aluminum Frame - Inner Glass

If you should have any questions regarding these data, please contact us.

very truly yours,

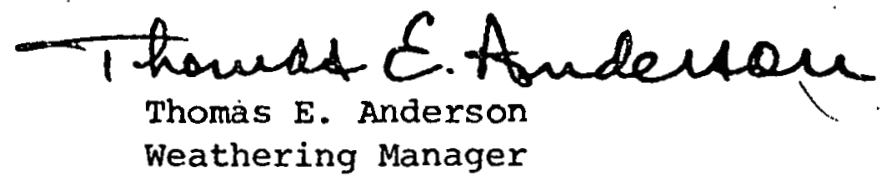

TEA : $1 f$ 
Seal Strip Corrective Action

The seal strip coupon specimen was retested at a level of $150^{\circ} \mathrm{F}$ for 500 hours. The result of post test examination is as follows:

pretest strength $47.9 \mathrm{lb}$

post test strength $45.5 \mathrm{lb}$

degradation $2.1 \%$ 


\section{7 Outgassing}

The objective of this test was to determine if the outgassing of organic material within the collector during solar cycling has an adverse effect on performance. The test sequence is as follows:

- Transmittance measurement of the glass

- Three cycles from 0 to $250 \mathrm{Btu} / \mathrm{hr}-\mathrm{ft}^{2}$ on a solar simulator

- Transmittance measurement of the glass

- 100 days of natural cycling in Phoenix, Arizona

- Transmittance measurement of the glass

Test Levels: $250 \mathrm{Btu} / \mathrm{hr}-\mathrm{ft}^{2}$ Solar Simulator, Natural Sunlight, Phoenix

Prerequisites: less than $10 \%$ degradation of transmittance

Examination: pretest transmittance 87.5 post simulator transmittance 85.4 post sunlight transmittance -84.6 total degradation due to outgassing was 2.9 percentage points or $3.3 \%$ 